УДК 005.95/.96

(C) 2012

Балановська Т. І., Гогуля О. П., Новак О. В., кандидати економічних наук

Національний університет біоресурсів і природокористування України

\title{
ФОРМУВАННЯ ЯКІСНОГО КАДРОВОГО ПОТЕНЦАЛУ ЯК ПЕРЕДУМОВА ЕФЕКТИВНОГО МЕНЕДЖМЕНТУ
}

\section{Рецензент - доктор економічних наук Х. 3. Махмудов}

\begin{abstract}
Проаналізовано склад керівників і спеціалістів сільськогосподарських підприємств України. Відображено матеріали сочіологічних досліджень вітчизняних та зарубіжних вчених стосовно характеристик керівних кадрів, а саме: їх професійних знань, умінь, досвіду, кваліфікації та впливу останніх на ефективність діяльності. Представлено визначені за результатами опитування основні вимоги до управлінських прачівників. Наведено матеріали щзодо підготовки фахівиів для аграрної та природоохоронної галузей. Обгрунтовано потребу формування якісного кадрового потенцііалу.
\end{abstract}

Ключові слова: кадровий потенціал, людські ресурси, кадри, керівники, спеціалісти, менеджмент.

Постановка проблеми. Для всіх організацій за будь-яких умов управління людськими ресурсами має першочергове значення, адже, як зазначає А. Моріта [1], ніякі теорія, програма чи урядова політика не можуть зробити підприємство успішним - це можуть зробити лише люди. У ринкових умовах господарювання роль працівника суттєво змінюється: 3 пасивного виконавця він перетворюється в активного учасника виробництва. Особливе місце в системі управління займають керівники і спеціалісти, які очолюють роботу колективів людей, визначають стратегію діяльності підприємства та його підрозділів, ставлять конкретні задачі й забезпечують необхідні умови для їхнього виконання. Таким чином, ефективність функціонування того чи іншого господарюючого суб'єкта передусім залежить від якісного складу управлінських працівників, їх особистих і ділових якостей, загальноосвітнього і кваліфікаційного рівнів.

Аналіз останніх досліджень і публікацій, у яких започатковано розв'язання проблеми. Дослідженню різнобічних аспектів проблем управління людськими ресурсами підприємств присвячено чимало праць вітчизняних і зарубіжних вчених: О. А. Бугуцького, О. Д. Гудзинського, В. М. Данюка, М. В. Дорошевої [2], Г. Десслера [3], А. П. Єгоршина [4], Й. С. Завадського, Ф. В. Зінов’єва, А. Я. Кибанова, А. М. Колота, Е. М. Короткова [1], Г. I. Купалової, Р. Марра,
М. І. Мурашко [5], В. М. Петюха, Ю. Г. Одєгова, Л. О. Шепотько, Г. Шмідта, Г. В. Щокіна, В. В. Юрчишина [6] та інших. Сучасна ж практика роботи 3 персоналом у сільськогосподарських підприємствах свідчить про відсутність належної уваги до розробки й реалізації ефективної кадрової політики, - кадровому забезпеченню не надається стратегічного значення і ціла низка питань, зокрема й формування якісного кадрового потенціалу, залишаються поза увагою.

Метою дослідження $\epsilon$ обгрунтування потреби в формуванні якісного кадрового потенціалу для забезпечення ефективної діяльності сільськогосподарських підприємств.

Основні результати дослідження. На початок 2010 року до складу керівників і спеціалістів сільськогосподарських підприємств України входило 178904 осіб (95,2% від потреби за штатом), із яких 44187 осіб - керівники. Із них лише 49,74 \% керівників і спеціалістів мало вищу освіту і 42,67 \% середню спеціальну (серед керівників цей показник становив 55,99 \% і 34,35 \% відповідно). Варто зазначити, що у 1997 році близько 90 \% керівників сільськогосподарських підприємств мали вищу освіту (табл. 1).

Як свідчать дані, далеко не всі керівники і головні спеціалісти сільськогосподарських підприємств мають вищу освіту (рис. 1). Проаналізувавши рівень освіти керівних кадрів сільськогосподарських підприємств у розрізі областей України, можна стверджувати, що чіткої закономірності в забезпеченості різних регіонів дипломованими кадрами не спостерігається.

Визначаючи типові особливості поведінки в процесі прийняття рішень, вчені встановили, що чим вищий рівень освіти керівників, тим урівноваженіші їх дії. Це підтверджується й нашими дослідженнями: зазвичай, господарства, які очолюють керівники 3 вищою освітою, мають кращі показники ефективності виробництва.

На початок 2010 року понад 30 \% керівників і спеціалістів сільськогосподарських підприємств мали вік понад 50 років, із них $8 \%$ - працівники пенсійного віку (табл. 1). 


\section{1. Кількісний та якісний склад керівників і спеціалістів сільськогосподарських підприємств} (на початок року)

\begin{tabular}{|c|c|c|c|c|c|c|}
\hline \multirow{2}{*}{ Показники } & \multicolumn{2}{|c|}{ Керівники і спеціалісти, усього } & \multicolumn{3}{|c|}{ У тому числі керівники } \\
\cline { 2 - 7 } & 1998 р. & 2010 p. & $\begin{array}{c}2010 \text { p. у \% } \\
\text { до 1998 p. }\end{array}$ & 1998 p. & 2010 p. & $\begin{array}{c}2010 \text { p. у \% } \\
\text { до 1998 p. }\end{array}$ \\
\hline $\begin{array}{c}\text { Передбачено посад } \\
\text { за штатом, тис. осіб }\end{array}$ & 407,33 & 187,87 & 46,12 & 14,01 & 44,25 & 315,85 \\
\hline $\begin{array}{c}\text { Усього працівників, } \\
\text { тис. осіб }\end{array}$ & 396,10 & 178,90 & 45,17 & 13,98 & 44,19 & 316,09 \\
\hline У т. ч.: мають вищу & & & & & & \\
освіту, тис. осіб & 132,83 & 88,99 & 66,99 & 12,33 & 24,74 & 200,65 \\
\% & 33,53 & 49,74 & $+16,21$ & 88,1 & 55,99 & $-32,11$ \\
\hline Мають вік & & & & & & \\
понад 50 років, тис. осіб & 111,04 & 59,61 & 53,68 & 4,94 & 17,29 & 350,0 \\
\%; & 27,26 & 33,32 & $-6,06$ & 35,26 & 39,14 & $+3,88$ \\
пенсійний вік, тис. осіб & 22,80 & 14,36 & 62,98 & 0,83 & 3,55 & 427,71 \\
\% & 5,76 & 8,03 & $-2,27$ & 5,9 & 8,04 & $+2,14$ \\
\hline
\end{tabular}

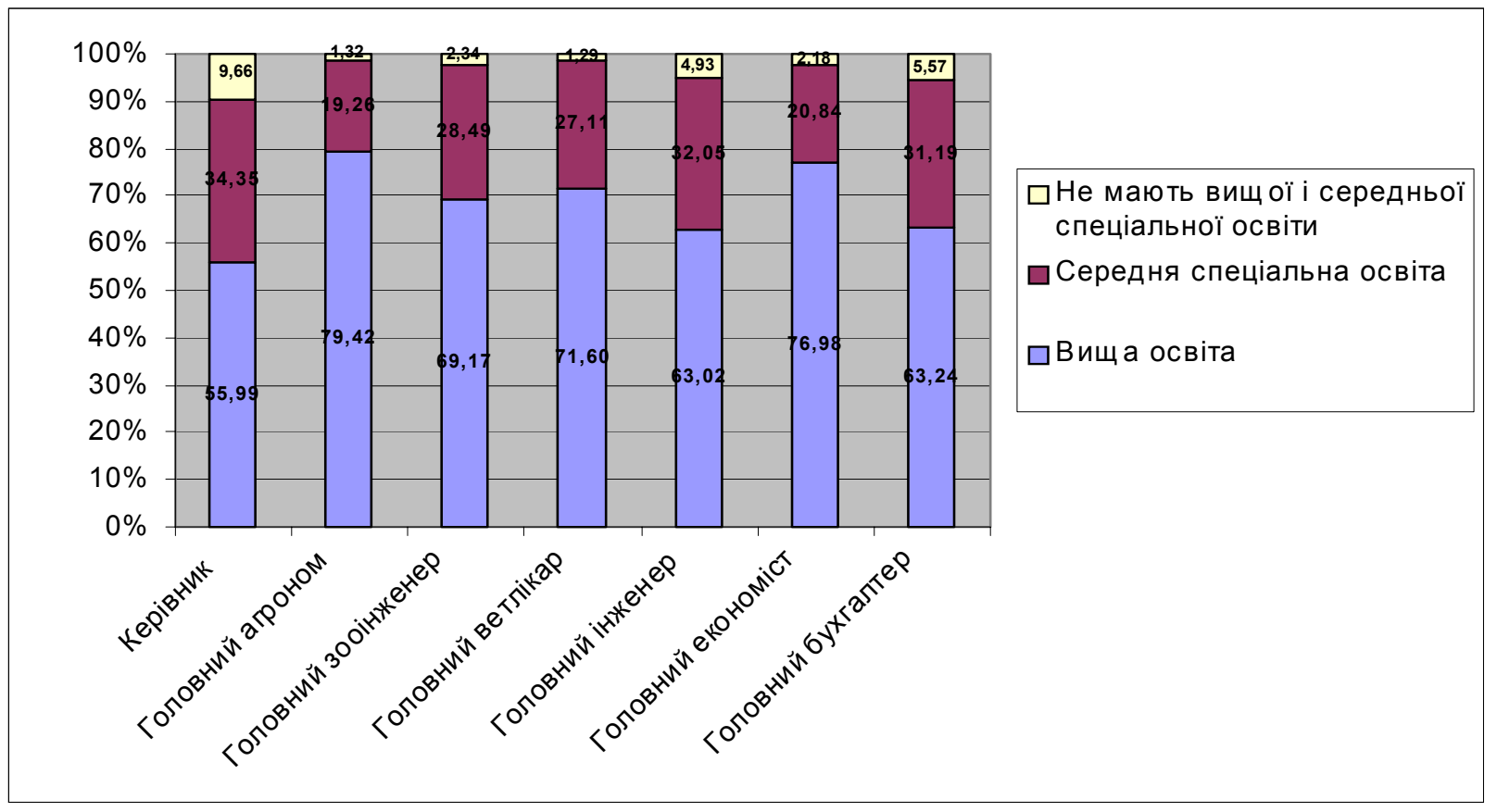

\section{Рис. 1. Рівень освіти керівників і головних спеціалістів сільськогосподарських підприємств, $2009 \mathrm{p}$.}

Серед керівників сільськогосподарських підприємств збільшилася частка працівників передпенсійного і пенсійного віку (близько 40 \%).

Наукою поки що не виявлено вагомих доказів залежності між віком і ефективною діяльністю керівників усіх рангів. Наприклад, А. Моріте (засновнику і багаторічному керівнику всесвітньовідомої «Соні Корпорейшн») у день заснування фірми було лише 25 років. Свій перший мільйон майбутній мільярдер і президент «Оксидентал петролеум» А. Хаммер заробив у 21 рік, очолюючи без відриву від навчання в уні- верситеті невеличку фармацевтичну фірму. У той же час Л. Якокка, ставши в 36-річному віці віце-президентом (а потім президентом) «Форд мотор компані», через чверть століття приводить до тріумфу корпорацію «Крайслер», яка була незадовго до цього на межі банкрутства [2]. Отже, вік керівника не може бути перевагою чи недоліком для того, щоб ефективно управляти, все залежить від кожного конкретного претендента на посаду керівника й особливостей діяльності підприємства. Матеріали ж соціологічного опитування [3] свідчать, що найбільш раціона- 
льним для роботи на посаді керівника підприємства вважається вік від 40 до 50 років. У цей період життя керівник має відповідні професійні знання і вміння, достатній досвід, високу кваліфікацію, нормальне здоров'я і працездатність. Окрім того, згідно 3 результатами наукових досліджень [4], у більш досвідчених керівників (які мають стаж роботи на посаді керівника понад 10 років), готовність до прийняття рішень в умовах ризику нижча, ніж у керівників із меншим стажем роботи.

За результатами проведених нами досліджень, серед перших керівників сільськогосподарських підприємств України переважна більшість має технічну освіту. Сучасний керівник повинен володіти різноманітними знаннями в сфері економіки, управління, бізнесу і психології, а також спеціальних наук, пов'язаних із діяльністю підприємства. Тому управлінські функції повинні виконуватися спеціалістами-управлінцями, а покладання їх на технологів (агрономів, зоотехніків, ветеринарів) було результатом фактичної відсутності системи підготовки фахівцівменеджерів. Однак у базовій технічній освіті також є свої позитивні сторони: практика показує, що люди, які зуміли оволодіти складними технічними i математичними дисциплінами, потім, пройшовши курси перепідготовки, прекрасно справляються із вирішенням економічних i управлінських задач.

Опитування управлінських працівників сільськогосподарських підприємств (у ході проведеного анкетування) дало можливість визначити найбільш значущі види знань для забезпечення виконання обов'язків менеджера (табл. 2). Результати даного дослідження доцільно застосовувати при здійсненні процедури підбору персоналу, коли в ході вивчення рівня підготовки претендентів варто звернути увагу на ті види знань, які, на думку мене- джерів-практиків, є найважливішими.

Переважна більшість респондентів найбільш важливими визначили економічні знання. Дійсно, в сучасних умовах дефіциту фінансових ресурсів і прагнення всіх учасників ринку отримати максимальні прибутки, управлінці будь-якого рівня вимушені, приймаючи рішення, враховувати їх економічну доцільність. Крім того важливим вважаються управлінські й правові знання, рівень яких визначається спеціальною підготовкою, а важливість - необхідністю розширення методів ефективного впливу на підлеглих та уникнення правових проблем шляхом врахування юридичних норм у процесі прийняття управлінських рішень. В умовах орієнтації системи менеджменту на отримання короткотермінового прибутку важливість соціально-психологічних i технічних знань невиправдано занижується; результати анкетування вказують на невисокий рівень підтримки їх із боку опитаних (сумарний ваговий коефіцієнт дорівнює 0,157 та 0,146 відповідно). Дійсно, застосування таких видів знань (особливо в нинішніх умовах) не завжди передбачає отримання економічного ефекту в короткостроковій перспективі, але в цілому для ефективного функціонування підприємства вони незамінні й актуальні, оскільки передбачають можливість формування і підтримки сприятливого для ефективної праці мікроклімату в трудовому колективі, а також дотримання технічних i технологічних вимог виробництва, реалізації, обліку продукції тощо.

Процедура відбору управлінських працівників передбачає пошук найкращих кандидатів, тих, які будуть якнайповніше відповідати потребам організації. Беручи до уваги глибину знань, необхідних управлінському працівнику для належного виконання своїх функцій, можна констатувати,

2. Результати анкетування управлінських працівників за питанням «Які з визначених видів знань с найбільш значущцими для ефективного виконання Ваших обов'язків в організації?»

\begin{tabular}{|c|c|c|c|c|c|c|}
\hline \multirow{2}{*}{$\begin{array}{c}\text { Фактор } \\
\text { (відповідь на питання) }\end{array}$} & \multicolumn{5}{|c|}{ Рівень важливості фактора } \\
\cline { 2 - 6 } & $\begin{array}{c}\text { на думку керівни- } \\
\text { ків господарств }\end{array}$ & $\begin{array}{c}\text { на думку інших } \\
\text { управлінських } \\
\text { працівників }\end{array}$ & $\begin{array}{c}\text { сумарний } \\
\text { ваговий } \\
\text { коефіцієнт }\end{array}$ & $\begin{array}{c}\text { підсумковий } \\
\text { ранг }\end{array}$ \\
\cline { 2 - 6 } & $\begin{array}{c}\text { ваговий } \\
\text { коефіцієнт }\end{array}$ & ранг & $\begin{array}{c}\text { ваговий } \\
\text { коефіцієнт }\end{array}$ & ранг & & 1 \\
\hline Економічні & 0,337 & 1 & 0,323 & 1 & 0,330 & 2 \\
\hline Управлінські & 0,184 & 2 & 0,186 & 3 & 0,185 & 4 \\
\hline Соціально-психологічні & 0,162 & 4 & 0,152 & 4 & 0,157 & 3 \\
\hline Правові & 0,176 & 3 & 0,189 & 2 & 0,183 & 5 \\
\hline
\end{tabular}

Примітка. Розраховано за результатами анкетування, проведеного серед управлінських працівників сільськогосподарських підприємств Житомирської області, 2009 р. 
що рівень кваліфікації є одним із важливих параметрів у забезпеченні якості кадрового потенціалу. Крім рівня теоретичної підготовки, який відображений у відповідних документах про освіту, важливо також враховувати інші критерії, одним iз яких $є$ стаж роботи на підприємстві чи галузі. Так, на думку анкетованих керівників, які беруть участь у процедурі відбору управлінських працівників сільськогосподарських підприємств (табл. 3), стаж роботи за спеціальністю у вітчизняних підприємствах є найбільш важливим критерієм на сьогодні (ваговий коефіцієнт становить 0,332). Керівники звертають увагу на освітній рівень (0,306), рідше, на жаль, на успішність навчання у вищих навчальних закладах $(0,196)$ i стажування за кордоном $(0,165)$.

Зважаючи на факт насичення навчальних планів підготовки спеціалістів різного профілю дисциплінами економічного, управлінського та правового циклів знань, випускників вищих навчальних закладів при відборі на вакантні посади керівників необхідно оцінювати 3 обов'язковим урахуванням успішності навчання зі згаданих предметів, адже вона вказує на якість знань претендента. Важливим є також те, що чимало студентів аграрних вищих навчальних закладів від'їджають на навчання, стажування за кордон; цим самим вони можуть принести користь, впроваджуючи свої знання і набутий досвід роботи 3 новою технікою, новітніми технологіями в практику вітчизняних сільськогосподарських підприємств.

Таким чином, сьогодні актуальним залишається питання якісної професійної підготовки керівних кадрів. Нині кадри для аграрної сфери в Україні готують 20 вищих навчальних закладів III-IV рівнів акредитації та 118 вищих навчальних закладів I-II рівнів акредитації. На денній та заочній формах навчається понад 148 тисяч спеціалістів, у тому числі у вищих навчальних закладах III-IV рівнів акредитації - понад 75 тисяч студентів. У динаміці з'являються якісно нові спеціальності, що зумовлено потребою виробництва. Однак питома вага студентів, які їх отримують, поки що незначна.

Щоб управляти сучасним колективом грамотних, кваліфікованих працівників, керівник повинен бути ерудованим, високоосвіченим. Світова практика стверджує, що керівником, так само як i художником, скульптором, композитором тощо, може бути лише незначний відсоток людей, які мають відповідні, закладені природою й набуті протягом життя здібності, навіть певний талант. Відповідність природних даних бажанню керувати підприємством, а також наявність природного інтелекту в сукупності 3 високим професіоналізмом мають вирішальне значення для успішної кар'єри менеджера [5]. В цілому можна сказати, що лише кожний десятий керівник сільськогосподарських підприємств має такі управлінські й організаційні знання та здібності, які роблять його стабільно надійним керівником. Відчувається потреба у працівниках нових професій для управлінської роботи, керівниках нового типу, які б мали знання у галузі маркетингу, менеджменту, права, володіли іноземними мовами й новими технологіям, а також характеризувалися високою здатністю до навчання.

Особливої уваги підготовці спеціалістів, які б відповідали запитам ринку, надає Національний університет біоресурсів i природокористування України - лауреат Українського національного конкурсу якості. Університет здійснює підготовку фахівців за наступними освітньо-кваліфікаційними рівнями: молодший спеціаліст - за 30 спеціальностями, бакалавр - за 28 напрямами, спеціаліст -

\section{3. Результати анкетування управлінських працівників за питанням «Які критерії оцінки} рівня кваліфікації Ви кладете в основу у процесі відбору працівників?»

\begin{tabular}{|c|c|c|c|c|c|c|}
\hline \multirow{3}{*}{ Критерії (відповіді на питання) } & \multicolumn{6}{|c|}{ Рівень важливості критерію } \\
\hline & \multicolumn{2}{|c|}{$\begin{array}{l}\text { на думку керівни- } \\
\text { ків господарств }\end{array}$} & \multicolumn{2}{|c|}{$\begin{array}{c}\text { на думку інших } \\
\text { управлінських } \\
\text { працівників }\end{array}$} & \multirow{2}{*}{$\begin{array}{l}\text { сумарний } \\
\text { ваговий } \\
\text { коефіцієнт }\end{array}$} & \multirow{2}{*}{$\begin{array}{c}\text { підсум- } \\
\text { ковий } \\
\text { ранг }\end{array}$} \\
\hline & $\begin{array}{c}\text { ваговий } \\
\text { коефіцієнт }\end{array}$ & ранг & $\begin{array}{c}\text { ваговий } \\
\text { коефіцієнт }\end{array}$ & ранг & & \\
\hline Стажування за кордоном & 0,166 & 4 & 0,165 & 4 & 0,165 & 4 \\
\hline $\begin{array}{l}\text { Стаж роботи за спеціальністю } \\
\text { у вітчизняних господарствах }\end{array}$ & 0,345 & 1 & 0,319 & 1 & 0,332 & 1 \\
\hline Освітній рівень & 0,303 & 2 & 0,310 & 2 & 0,306 & 2 \\
\hline Успішність навчання у ВНЗ & 0,186 & 3 & 0,206 & 3 & 0,196 & 3 \\
\hline
\end{tabular}

Примітка. Розраховано за результатами анкетування, проведеного серед управлінських працівників сільськогосподарських підприємств Житомирської області, 2009 р. 


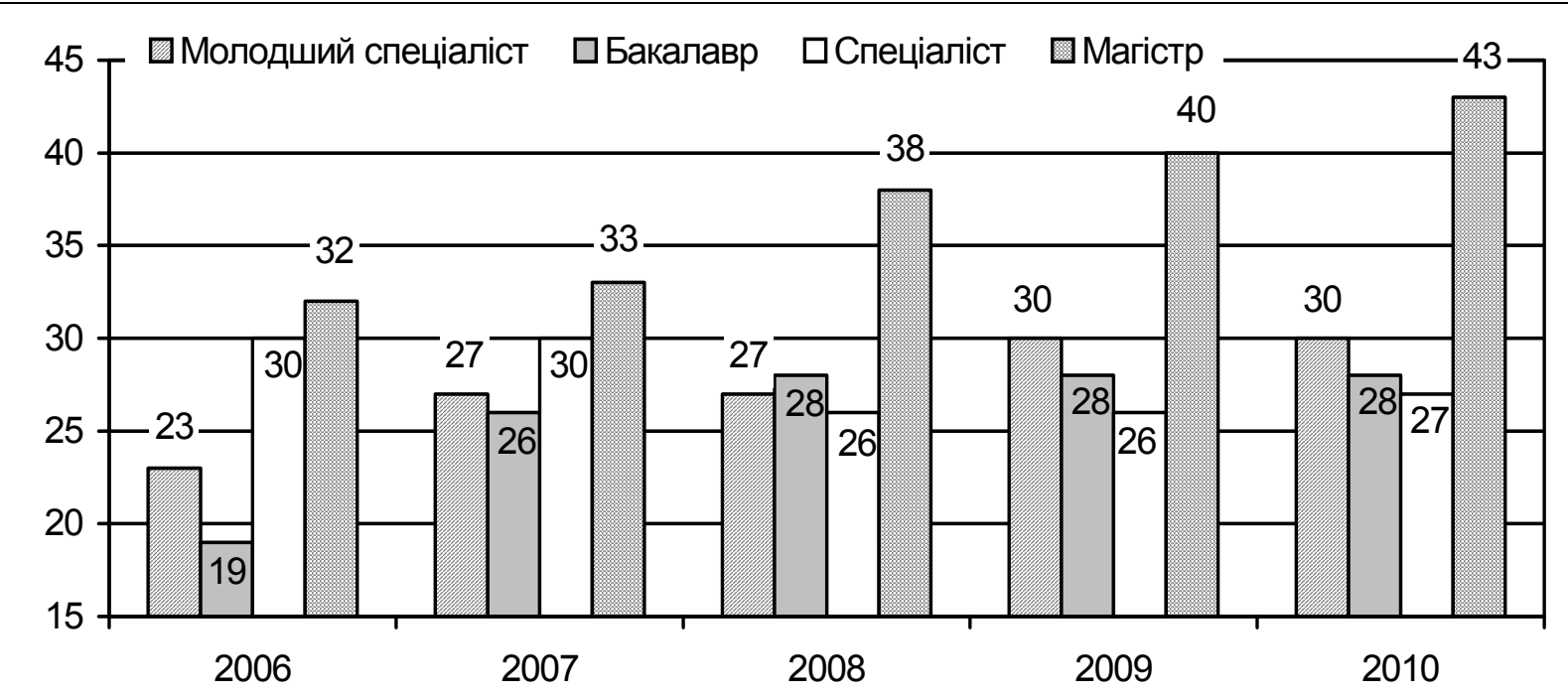

Рис. 2. Динаміка кількості напрямів і спеціальностей у Національному університеті біоресурсів і природокористування Украӥни

за 27 спеціальностями і більше ніж 50 спеціалізаціями, магістр - за 43 спеціальностями і понад 100 спеціалізаціями (рис. 2).

В організації навчального процесу на магістерських програмах беруть участь відомі вітчизняні й іноземні науково-педагогічні працівники і наукові співробітники, молоді люди, які отримали освіту в кращих зарубіжних університетах. Для формування у магістрів практичних навиків для викладання запрошуються спеціалістипрактики, виробничники. Магістерські програми університету представлені 43 спеціальностями, які користуються попитом на ринку. Вони дають змогу студентам будь-якого напряму спеціалізуватися в таких сферах, як дослідницька, педагогічна, експертно-контрольна й управлінська.

Неабияке значення при цьому мають також нові навчальні та дослідницькі лабораторії, центри й інститути, навчально-дослідні господарства (станціï), науково-інноваційні центри і т. п. Вони дають можливість об'єднати навчальну, наукову, дослідницьку та інноваційну діяльність університету з проблемами виробничої сфери. Остання, в свою чергу, має можливість коригувати дослід-

\section{БІБЛІОГРАФІЯ}

1. Антикризисное управление: Учебник / Под ред. Э. М. Короткова. - М.: ИНФРА-М, 2000. - С. 323.

2. Дорошева М. В. Подбор руководителя для конкретного коллектива. Подготовка резерва руководителей и выявление сотрудников с лидерским потенциалом / М. В. Дорошева// Управление персоналом. - 1997. - №8. - С. 36-43.

3. Десслер Гари. Управление персоналом / Пер. с англ. - М.: "Издательство БИНОМ", 1997. - С. 151. 4. Егоршин А.Г. Управление персоналом / ницьку і навчальну роботу. 3 цією метою університет використовує навчально-дослідні господарства, в яких представлено всі етапи виробництва, обробки та зберігання різних видів сільськогосподарської продукції.

Висновок. Таким чином, для успішної діяльності сільськогосподарських підприємств, що передбачає раціональне використання ресурсів та впровадження новітніх технологій, необхідною умовою $є$ наявність кваліфікованих, високоосвічених, конкурентоспроможних людських ресурсів. Сьогодні склалися певні умови для формування якісного кадрового потенціалу, який можна ефективно використовувати в аграрній, природоохоронній та інших галузях. Необхідно враховувати, що кадри можуть забезпечити максимальну віддачу лише в тому випадку, коли вони виконують роботу, яка відповідає їх інтересам, здібностям, знанням, рівню освіти. Для забезпечення ж ефективного менеджменту керівник завжди повинен пам'ятати, що, як зазначав Ф. Пікабіа [6], є лише один спосіб змусити людей іти за вами, а саме: рухатися вперед швидше, ніж вони.

А. Г. Егоршин. - Н. Новгород: НИМБ, 1997. C. 103-104.

5. Мурашко М. I. Менеджмент персоналу: Навч.практ. посіб. / М. І. Мурашко. - К.: Т-во “Знання", КОО, 2002. - С. 31.

6. Юрчишин В. Деякі методологічні засади кадрового забезпечення управління сільськогосподарськими підприємствами / В. Юрчишин, О. Бородіна // Економіка України. - 1996. № 1. - C. $48-55$. 